\title{
Enzo Neppi, Le babil et la caresse. Pensée du maternel chez Sartre
}

\section{Emanuele Kanceff}

\section{Q OpenEdition}

1 Journals

\section{Edizione digitale}

URL: https://journals.openedition.org/studifrancesi/39718

DOI: 10.4000/studifrancesi.39718

ISSN: 2421-5856

\section{Editore}

Rosenberg \& Sellier

\section{Edizione cartacea}

Data di pubblicazione: 1 décembre 2004

Paginazione: 406

ISSN: 0039-2944

\section{Notizia bibliografica digitale}

Emanuele Kanceff, «Enzo Neppi, Le babil et la caresse. Pensée du maternel chez Sartre», Studi Francesi [Online], 143 (XLVIII | II) | 2004, online dal 30 novembre 2015, consultato il 19 mai 2021. URL: http:// journals.openedition.org/studifrancesi/39718; DOI: https://doi.org/10.4000/studifrancesi.39718

Questo documento è stato generato automaticamente il 19 mai 2021.

\section{(c) $(1) \&$}

Studi Francesi è distribuita con Licenza Creative Commons Attribuzione - Non commerciale - Non opere derivate 4.0 Internazionale. 


\title{
Enzo Neppi, Le babil et la caresse. Pensée du maternel chez Sartre
}

\author{
Emanuele Kanceff
}

\section{NOTIZIA}

ENZO NEPPI, Le babil et la caresse. Pensée du maternel chez Sartre, New York - Paris, Peter Lang, s. d. («American University Studies», 210), pp. 180.

1 Sartre pare l'emblema dell'antinatura: mai in lui si trova l'attenzione nei confronti dell'intimità e di ciò che potremmo chiamare il "materno". Fin dalla nascita, fin da quel mancato taglio del cordone ombelicale che egli dice di non aver sentito, la madre gli è estranea così come gli è estranea la natura, che mai nelle sue pagine offre un aspetto accogliente, rasserenante, pacificato.

2 Non avendo conosciuto suo padre, è sulla madre che sembra accentrarsi il suo bisogno di negazione e di ribellione, ed è la sua figura che Sartre si applica a smantellare, come di un'estranea dalla quale si meraviglierebbe molto di apprendere d'esser nato.

3 Partendo da questi presupposti, il libro di Neppi finisce per dimostrare tutto l'opposto. L'opera di Sartre finisce con l'apparire una continua riflessione sotterranea attorno al femminile e al materno. Questo suo atteggiamento equivale ad una nostalgica reminiscenza prenatale in cui la comunione con la natura, con il mondo, con la madre è perfetta. Ciò lo conduce, alla fine, ad una concezione di "autenticità" che, lungi dall'essere un'avventura solitaria, è un invito alla reciprocità. È in tale dialettica ritrovata che la madre e il figlio, frammento della sua carne, possono ricongiungersi. 